\title{
Integrasi Budaya, Pendidikan, dan Politik dalam Dakwah Nahdlatul Wathan (NW) di Lombok: Kajian Biografi TGH. Zainuddin Abdul Madjid
}

\author{
Saipul Hamdi \\ Fakultas Ilmu Sosial dan Ilmu Politik Universitas Mataram \\ (e-mail: hamdiugm@gmail.com)
}

\begin{abstract}
Nahdlatul Wathan (NW) is a national religious organization that established in Lombok by Tuan Guru Haji (TGH) Muhammad Zainuddin Abdul Madjid in 1953. Although NW is the minority group in the context of national level compare to Nahdlatul Ulama and Muhammadiyah organization, but it has become the majority religious group in Lombok and noted as the most powerful and successful organization in term of religious da'wa development, education and politic. Since 1937-2018 NW has 1600 branches of madrasah and majlis ta'lim spread out all around Indonesian archipelago, including in the capital city of Indonesia Jakarta. In 2008-2018 NW took over the political authority when its leader TGH. Muhammad Zainul Majdi inaugurated as the Governor of West Nusa Tenggara province for two periods. In doing so, this article examines the way the founder of NW has carried NW into the highest achievement, especially the way TGH. Zainuddin integrates the cultural aspects such as local symbol, art, education, and politic in Nahdlatul Wathan's da'wa activities. This research is qualitative research that data based on references. Most data are from the works of TGH. Zainuddin and any kinds of literature that especially related to him and NW.
\end{abstract}

Nahdlatul Wathan (NW) adalah organisasi keagamaan nasionalis yang didirikan di Lombok oleh Tuan Guru Haji (TGH) Muhammad Zainuddin Abdul Madjid pada tahun 1953. Meskipun NW adalah organisasi minoritas dalam konteks nasional dibandingkan dengan Nahdlatul Ulama dan organisasi Muhammadiyah, tetapi telah menjadi organisasi keagamaan mayoritas di Lombok dan tercatat sebagai organisasi paling kuat dan sukses dalam hal pengembangan dakwah, pendidikan, dan politik. Sejak 1937-2018 NW memiliki 1600 cabang madrasah dan majlis ta'lim yang tersebar di seluruh kepulauan Indonesia, termasuk di ibu kota Indonesia Jakarta. Pada 2008-2018 NW mengambil alih otoritas politik ketika pemimpinnya TGH. Muhammad Zainul Majdi dilantik sebagai Gubernur Provinsi Nusa Tenggara Barat selama dua periode. Dengan demikian, artikel ini meneliti cara pendiri NW telah membawa NW ke pencapaian tertinggi, terutama cara TGH. Zainuddin mengintegrasikan aspek budaya seperti simbol lokal, seni, pendidikan, dan politik dalam kegiatan dakwah NW. Penelitian ini adalah penelitian kualitatif yang datanya berdasarkan studi pustaka. Sebagian besar data berasal dari karya TGH. Zainuddin dan segala jenis literatur yang terutama berkaitan dengannya dan NW.

Keywords: Nahdlatul Wathan; Zainuddin; integration, cultural; da'wa 


\section{Pendahuluan}

Nahdlatul Wathan merupakan organisasi Islam terbesar di Lombok yang bergerak dalam bidang pendidikan, sosial dan dakwah. Embrio Nahdlatul Wathan dimulai dari pendirian Pondok Pesantren Al-Mujahidin pada tahun 1937. Pondok pesantren ini merupakan lembaga pertama yang didirikan oleh TGH. Muhammad Zainuddin Madjid setelah pulang dari Makkah, dan kemudian terdaftar secara resmi sebagai ormas Islam pada tahun 1953 (Noor et al. 2004; Syakur 2006). Literatur lain menyatakan bahwa Nahdlatul Wathan berdiri pada tanggal 25 Agustus 1937 (Nahdi 2012). Nahdlatul Wathan berada di posisi tengah antara NU dan Muhammadiyah Dalam praktik ibadah dan ritual amaliah Nahdlatul Wathan lebih dekat ke Nahdlatul Ulama, sedangkan dalam konsep pembangunan pendidikan sama dengan Muhammadiyah. Nahdlatul Wathan tidak memiliki pondok pesantren yang khusus, ia lebih fokus pada pengembangan pendidikan formal seperti madrasah, sekolah dan perguruan tinggi (Hamdi 2014: 24). Untuk mendukung pendidikan keagamaan, Nahdlatul Wathan di pusat Kota Pancor hanya mendirikan Ponpes setingkat mahasiwa (ma'had 'ali) yang dinamakan Ma'had Darul Qur'an walHadits. Semua lulusan Aliyah diharapkan untuk menimba ilmu di Ponpes Ma'had sambil kuliah di perguruan tinggi lain di lingkungan kampus Nahdlatul Wathan. Meskipun di tingkat cabang lembaga pendidikan Nahdlatul Wathan di beberapa desa membangun ponpes, tetapi jumlahnya sangat terbatas.

Praktik dakwah Nahdlatul Wathan tidak hanya melalui pendidikan formal, tetapi juga melalui ceramah-ceramah umum (pengajian) yang dilakukan secara bergantian dari kampung ke kampung yang melibatkan jumlah massa yang besar. Di dalam pengajian tersebut berbagai kegiatan ikut menyertai misalnya nyanyian lagu-lagu Nahdlatul Wathan, pembacaan wasiat, melempar uang koin untuk amal, dan penjualan asesoris Nahdlatul Wathan berupa foto TGH. Zainuddin, kalung dan cincin yang di dalamnya terdapat foto beliau. Simbol-simbol legenda lokal juga seringkali digunakan baik di dalam teks Nahdlatul Wathan maupun dalam ceramahceramah TGH. Zainuddin yang berpengaruh besar pada tingkat penerimaan dan kepercayaan masyarakat atas dakwah tersebut. Berangkat dari asumsi ini artikel juga bertujuan untuk mengeksplorasi tentang transformasi yang berkembang di dalam dakwah Nahdlatul Wathan, unsur-unsur kebudayaan dan seni yang digunakan di dalam dakwah tersebut, dan peran simbol-simbol tersebut sebagai sumber inspirasi TGH. Zainuddin dalam mengembangkan praktik dakwahnya dan pembentukan karakter dakwah yang damai dan moderat.

Dengan tujuan-tujuan tersebut, artikel ini mencoba untuk mengkerangkai transformasi dakwah yang dilakukan oleh Nahdlatul Wathan dengan kerangka teori gerakan sosial. Dalam konteks ini adalah gerakan sosial yang dilakukan oleh Tuan Guru Haji (TGH) Muhammad Zainuddin Abdul Madjid di dalam organisasi Nahdlatul Wathan (1898-1997), khususnya berhubungan dengan pendekatan dakwah yang integratif yakni memadukan berbagai unsur kebudayaan seperti seni, simbol, pendidikan dan politik. Integrasi unsur-unsur 
tersebut dalam dakwah Nahdlatul Wathan telah berkontribusi besar di dalam percepatan pembangunan Nahdlatul Wathan di masyarakat. Meskipun dakwah Nahdlatul Wathan mengalami tantangan di awal berdirinya 1930an karena kesalahan persepsi dan miskomunikasi dari masyarakat, akan tetapi setelah memahami pendekatan yang digunakan oleh pendiri Nahdlatul Wathan masyarakat mulai sadar memberikan dukungan penuh atas kegiatan dakwah tersebut. Bahkan elemen masyarakat yang dulunya menentang telah bergabung dan menjadi bagian penting di dalam pengembangan dakwah Nahdlatul Wathan.

Data untuk penulisan artikel ini diperoleh dari riset pustaka mengenai TGH. Muhammad Zainuddin Abdul Madjid dan organisasi Nahdlatul Wathan. Selain itu data juga diperoleh dari hasil wawancara dengan berbagai tokoh Nahdlatul Wathan dan masyarakat yang mengenal sosok Tuan Guru dan mengetahui perkembangan organisasi Nahdlatul Wathan. Data pendukung diperoleh dari hasil observasi lapangan mengenai praktik keagamaan yang dijalani oleh sebagian jama'ah dan anggota Nahdlatul Wathan.

\section{Transformasi Islam dalam Dakwah Integratif}

Salah satu kunci kesuksesan Tuan Guru Haji (TGH) Zainuddin dalam membangun dan mengembangkan Nahdlatul Wathan sebagai salah satu ormas Islam terbesar di Lombok adalah kemampuannya untuk mengintegrasikan budaya, seni, pendidikan dan politik dalam dakwahnya. Integrasi budaya, seni dan politik dalam kultur dakwah yang dikonstruksi oleh TGH. Zainuddin merupakan terobosan besar pada masanya karena masyarakat Lombok secara umum termasuk tokoh agama dan adat terjebak dalam dikotomi "budaya" dan "agama" dalam arti ortodok. Mereka tidak mampu mendialogkan dan mensinergikan ketiga bidang tersebut, bahkan tidak jarang konflik dan kekerasan muncul karena pilihanpilihan media dan metode yang digunakan bertentangan dengan tradisi lokal. Tafsir dan wacana baru yang dibawa oleh sebagian kelompok Salafi sebagai bentuk purifikasi sulit diterima oleh masyarakat lokal.

Islam di Lombok dalam sejarah dibawa oleh keturunan dari Sunan Giri yaitu Sunan Prapen pada abad ke-15 ketika kerajaan Islam mulai eksis di pulau Jawa (Jamaludin 2011). Runtuhnya kerajaan Majapahit dan berdirinya kerajaan Islam memberi ruang yang lebih luas untuk penyebaran agama Islam. Kekuatan politik dan ekonomi dari kerajaan Islam memfasilitasi para wali untuk menyebarkan Islam ke seluruh kepulauan Nusantara. Penyebaran Islam memiliki dinamika yang berbeda-beda di setiap daerah. Sebagian daerah masyarakatnya dengan mudah menerima dan sebagian menolak bahkan menentang masuknya pemahaman yang diklaim baru karena dominasi ideologi Hindu, Buddha dan kepercayaan lokal pada waktu itu (Budiwanti 2000; Syakur 2006). Lombok memiliki keunikan sendiri ketika terjadi Islamisasi oleh para muballigh dari Jawa, di mana pertentangan adat dan praktik keagamaan cukup alot. Tawar menawar kekuasaan juga menjadi isu ketika Islam mulai merambah gumi Sasak. Masya- 
rakat khawatir jika Islam dapat merusak local wisdom dan praktik-praktik ritual yang telah berkembang dan diwarisi secara turun temurun. Keberadaan agama baru ini juga dapat mengubah sturuktur sosial, kekuasaan dan sistem politik kerajaan di masyarakat. Walaupun berhasil melakukan negosiasi dengan tokoh-tokoh lokal untuk tujuan penyebaran Islam secara damai, bukan invasi politik, akan tetapi perkembangan Islam mengalami stagnasi karena gesekan dan pertentangan praktik kepercayaan lokal Wetu Telu dan agama yang belum tuntas.

Kehadiran TGH. Zainuddin di awal abad ke20 membawa pendekatan baru dalam proses Islamisasi di Lombok. Peran TGH. Zainuddin sebagai tokoh baru memberikan perubahan yang signifikan di masyarakat. Dia mampu memobilisasi massa dalam jumlah besar secara konsisten baik untuk pembangunan tempat pendidikan, ibadah maupun ritual keagamaan. Setiap pengajiannya tidak pernah sepi, jama'ah datang dari berbagai kampung untuk hadir di pengajiannya. Metode dan pendekatan apa yang digunakan oleh TGH. Zainuddin sehingga mampu melakukan perubahan yang massif terutama di bidang pendidikan dan keagamaan (Baharuddin 2007; Hamdi 2011). Saya berargumen bahwa TGH. Zainuddin mampu mengintegrasikan berbagai pendekatan termasuk seni, budaya, pendidikan dan politik di dalam dakwahnya. Skill dan potensi yang beliau miliki juga dapat dimanfaatkan dengan baik. TGH. Zainuddin yang dikenal ahli sastra Arab membuat lagu-lagu, sair dan pantun yang berisikan pesan moral, semangat perjuangan dan ajaran agama. TGH.
Zainuddin juga dikenal cerdas membaca peluang, perubahan sosial dan berani membuat terobosan dan memberikan jalan tengah untuk mengatasi masalah tersebut. Ketika para tokoh agama sibuk dengan dunia pesantren, TGH. Zainuddin justru meninggalkan pesantren dan membangun madrasah. Dia sadar bahwa madrasah jauh lebih efektif, modern, sistematis dan outputnya dapat bersaing di pasar kerja. Pesantren pada waktu itu tidak menggunakan kurikulum nasional dan tidak memiliki ijazah. Walaupun di awal-awal banyak tantangan dan cibiran yang dihadapi karena meninggalkan sistem pesantren, tetapi waktulah yang menjawab kekhawatiran masyarakat pada waktu itu. Madarasah menjadi lembaga pendidikan alternatif yang juga diadopsi oleh pemerintah. Gerakan pembangunan madrasah inilah yang membuat nama TGH. Zainuddin semakin dikenal oleh masyarakat di seluruh penjuru Lombok karena sebagian besar madrasah berafiliasi dan menggunakan kata NW untuk nama akhir madrasah itu (Nahdi 2012; Nu'man 1999).

Keberhasilan dakwah Islamiyah oleh TGH. Zainuddin juga karena faktor metode dan pendekatan dakwah yang digunakan. TGH. Zainuddin yang diyakini sebagai salah satu waliyullah di Lombok oleh para jama'ahnya seringkali mengadopsi metode Walisongo dalam berdakwah. Metode dakwah Walisongo yang dimaksud di sini adalah menggunakan budaya lokal sebagai media transformasi nilainilai keislaman. TGH. Zainuddin tidak mewacanakan pemurnian Islam "Salafisasi" atau menentang praktik budaya lokal secara ekstrim tetapi sebaliknya menggunakan praktik- 
praktik lokal tersebut sebagai modal sosial dan modal kultural untuk mengembangkan ajaran Islam. Dia sangat akomodatif dan longgar dengan praktik budaya lokal, sebagai contoh, TGH. Zainuddin tidak pernah menekan perempuan Sasak untuk menggunakan jilbab dalam kesehariannya. Perempuan Sasak dalam kesehariannya biasa menggunakan handuk atau kain kecil untuk menutupi kepala mereka, bahkan sebagian perempuan Sasak tidak berjilbab sama sekali (Smith 2014). Bagi TGH. Zainuddin yang terpenting adalah meereka tidak melupakan kewajiban pokok yakni shalat lima waktu. Berbeda ketika mereka di madrasah, dia mengharuskan semua siswa menggunakan jilbab.

TGH. Zainuddin juga seringkali menggunakan simbol-simbol lokal sebagai alat legitimasi dakwah seperti penggunaan istilah gunung Rinjani, Dewi Anjani, Amaq Milasih, Amaq Anom dan kerajaan Selaparang (Hamdi dan Smith 2012). Penggunaan nama-nama tokoh legenda lokal yang berpengaruh seperti Dewi Anjani (putri raja Selaparang) yang memiliki kekuatan spiritual dan diyakini mangku (penjaga) Gunung Rinjani secara tidak langsung menguatkan posisi TGH. Zainuddin di tingkat grassroot. Masyarakat lebih yakin lagi tentang kekuatan TGH. Zainuddin karena mampu berkomunikasi dengan tokoh-tokoh tersebut di alam metafisika (Smith 2012). Kultur mistik yang kental di habitus masyarakat Lombok sangat cocok dengan wacana dan kultur keagamaan yang dikonstruk oleh TGH. Zainuddin. Cerita tentang peritistiwa gaib di pengajiannya menjadi daya tarik sendiri, apalagi testimoni masyarakat tentang kekeramatan TGH. Zainuddin selalu muncul dalam pengajian.
Fenomena di atas menunjukkan kelihaian sosok TGH. Zainuddin dalam membaca perkembangan sosial, budaya dan politik di masyarakat. TGH. Zainuddin berhasil mengintegrasikan seluruh elemen dan modal yang terdapat di masyarakat. Integrasi agama dan praktik budaya lokal melahirkan kultur "Islam NW" yang unik, di mana sinkretisme sangat harmonis dalam kultur baru tersebut. Wajar jika adanya pandangan miring tentang kultur keagamaan Nahdlatul Wathan yang dianggap berbau syirik karena ketidakpahaman kelompok luar dalam melihat kultur keagamaan Islam Nahdlatul Wathan secara komprehensif. Inilah kekuatan Nahdlatul Wathan ketika mampu menyatukan dan mengawinkan seluruh elemen yang ada dan membuat produk baru yang bisa menarik simpati masyarakat.

\section{Ritual Hizib, Tarekat Hizib dan Wasiat TGH. Zainuddin dalam Kasidah}

Agama dan seni tidak dapat dipisahkan dalam realitas kehidupan manusia. Seni menjadi bagian hidup yang menyatu dalam setiap gerak dan emosi. Agama-agama di dunia mulai dari Yahudi, Hindu, Budha, Kristen dan Islam memiliki tradisi kesenian yang kuat. Kitab suci yang mereka miliki harus dibaca dengan nada tertentu, belum lagi lirik atau isi kitab suci terbsebut yang mengandung nilai sastra yang tinggi karena berasal dari wahyu Tuhan (Jasper 2006). Bahkan dalam tradisi agama tertentu seperti Kristen musik adalah bagian yang sangat penting dalam ibadah mereka. Tanpa musik ibadah mereka kurang khusuk dan kurang menghayati sampai ke dalam hati. Begitu juga dengan Islam, meskipun sebagian 
ulama mengharamkan musik, akan tetapi sebagian juga membolehkan. Musik telah menjadi bagian dari dakwah Islamiyah sejak masa Rasulullah. Rhoma Irama pernah mempopulerkan istilah nada dan dakwah bersama Kyai Zainuddin MZ. Ritual-ritual dalam agama Islam seperti tarian Sufi Mevlevi Sema yakni meditasi fisik dengan tarian berputer yang dibuat oleh Jalaluddin Muhammad BalkhiRumi pada abad ke-13 dari Konya Turki juga diiringi dengan musik (Binbaş 2005: 58). Perlombaan tilawah al-Qur'an, rebana kasidah dan ritual burdah juga melibatkan seni suara dan alat musik.

Sebagai tokoh yang ahli dalam sastra, seni tidak dapat dipisah dari kehidupan TGH. Zainuddin. Sebagian besar ritual-ritual Nahdlatul Wathan melibatkan unsur seni dan musik di dalamnya. Selain menciptakan lagu-lagu berbahasa Arab, Sasak dan Indonesia, dia juga menyusun buku Hizib yang bacaannya membutuhan nyanyian. Buku Hizib adalah salah satu karya besar TGH. Zainuddin yang terus dibaca bahkan menjadi "kitab suci" bagi jama'ah Nahdlatul Wathan. Buku hizib biasanya dibaca satu kali seminggu setiap malam jumat secara berjama'ah di mushalla atau di masjid. Kegiatan berhizib ini kemudian menjadi ritual bagi jama'ah Nahdlatul Wathan sebagai bentuk kesetiaan, solidaritas dan simbol perjuagan bagi organisasi Nahdlatul Wathan. Dimana pun jama'ah Nahdlatul Wathan berada selalu membaca hizib. Hizib adalah kumpulan doa-doa para waliyulah, sair ulama, pilihan beberapa surat al-Qur'an yang dikumpulkan dan disusun ulang oleh TGH. Zainuddin (Habib dan Zuhdi 2012; Hadi 2010). Membaca hizib harus meng- gunakan ritme atau nada yang telah ditentukan. Nadanya terkadang rendah, sedang dan keras sesuai dengan makna doa yang dibacakan. Jika dikategorikan dalam musik, nyanyian hizib terkadang menggunakan nada pop, rock dan rep. Nada Hizib ini mirip dengan ritual Habsian dalam tradisi Islam Banjar, namun Hzib tidak disertai alat musik.

Hizib tidak hanya dibaca oleh orang Nahdlatul Wathan, tetapi juga oleh komunitas Muslim luar Nahdlatul Wathan yang lain. Di Kabupaten Kutai Kartanegara Kalimantan Timur misalnya, para jama'ah yang ikut membaca Hizib berasal dari etnis Madura, Kutai, Jawa dan Bugis. Mereka berpartisipasi dalam ritual Hizib yang dipimpin oleh warga Nahdlatul Wathan yang ikut dalam program transmigrasi di Kutai Kartanegara. Bahkan gaung Hizib juga sampai di negara tetangga seperti Malaysia yang dibawa oleh para TKI asal Lombok dan juga di negara-negara Timur Tengah seperti Mesir dan Arab Saudi yang digagas oleh para alumni madrasah Nahdlatul Wathan yang sedang menuntut ilmu di sana. Ini menandakan bahwa nilai-nilai yang terkandung dalam Hizib bersifat universal dan global dapat dipraktikkan di mana-mana. Dari wacana masyarakat lokal di Lombok bahwa Hizib yang berisi doa, sair dan ayat-ayat Qur'an ini diyakini memiliki kekuatan magis yang sangat ampuh. Hizib dijadikan benteng dan modal untuk melindungi diri dan komunitas mereka dari serangan musuh dan menjauhkan musibah. Bagi jama'ah Nahdlatul Wathan jika membaca Hizib mereka akan selamat samasama masuk surga bersama TGH. Zainuddin dan dimudahkan rezeki mereka. Hizib adalah 
salah satu identitas Nahdlatul Wathan dan membacanya bagian dari perjuangan pengembangan Nahdlatul Wathan karena di dalamnya terdapat doa-doa untuk menyebarkan ajaran Nahdlatul Wathan dan ajaran Islam ke seluruh alam. TGH. Zainuddin menggunakan kata simbol bendera Nahdlatul Wathan Iiwa'a nahdlatul wathan' untuk penyebarannya melalui hizib dan lembaga pendidikan di bawah naungan organisasi Nahdlatul Wathan.

Emile Durkheim berpendapat bahwa ritual adalah sistem kepercayaan masyarakat yang mengekspresikan hubungan yang suci (sacred) dan profane (tidak suci), alam yang tidak nyata dengan alam yang nyata. Ritual adalah ekspresi simbolik mengenai relasi sosial yang aktual, status dan peran individu dalam masyarakat (Durkheim 1995: 33). Dalam konteks berhizib para jama'ah sedang berkomunikasi dengan alam lain untuk meminta keselamatan dan kedamaian. Semua jama'ah khusuk dan hanyut dalam irama nyanyian hizib. Fungsi ritual bukan hanya kekuatan substansi materi ritualnya, akan tetapi juga berfungsi untuk menguatkan solidaritas sosial "social solidarity" kelompok dalam sebuah kekuatan sosial. Jadi jika ditarik dalam ritual hizib bahwa bukan hanya hizibnya yang tetap eksis, tetapi juga kekuatan komunalitas berjama'ah dalam membacanya. Jama'ah Nahdlatul Wathan yang kumpul berhizib secara tidak sadar ikut dalam penguatan relasi dan menjaga solidaritas persaudaraan mereka. Inilah salah satu kekuatan yang membuat organisasi Nahdlatul Wathan selalu eksis dan jama'ahnya tetap loyal dan istikomah dalam perjuangan. Orang yang berhizib atau memimpin hizib menempati status tertentu di kalangan para jama'ah. Dia dianggap "lebih NW" daripada yang jarang berhizib, lebih-lebih dia adalah seorang tuan guru maka kekuatan spiritual dan kesuciannya bertambah di mata masyarakat.

Sebagai seroang sufi beliau tidak merasa cukup jika tidak memiliki tarekat. Dia sadar sadar bahwa ada sesuatu yang kurang dalam dakwah agamanya yakni belum berkembangnya wacana tarekat yang lurus dan berpegang pada syariat. TGH. Zainuddin sagat berhati-hati dengan tarekat pada waktu itu karena muncul pro dan kontra di masyarakat Lombok terkait status pelaku tarekat yang terkesan keluar dari syariat Islam. Resistensi yang kuat dari kelompok Muslim ortodok yang mengklaim adanya penyimpangan syariat dalam praktik tarekat mendorong TGH. Zainuddin untuk membuat tarekat baru yang minimalis dan tidak kontroversial. Setelah mendapat petunjuk dari nabi Khidir, TGH. Zainuddin mendirikan kelompok tarekat yang dinamakan Tarekat Hizib Nahdlatul Wathan (Habib dan Zuhdi 2012). Tarekat ini berasal dari saripati hizib Nahdlatul Wathan yang berupa amalan-amalan pendek dan sederhana. Tarekat Hizib Nahdlatul Wathan diklaim sebagai tarekat akhir zaman melengkapi tarekat-tarekat sebelumnya yang dibuat oleh para ulama dan para waliyulah di seluruh dunia. Tarekat ini juga menjawab tantangan sosial terhadap menjamurnya kelompok tarekat di masyarakat Lombok yang diklaim "menyimpang" karena melupakan syariat. Tarekat Hizib diciptakan untuk menjaga iman jama'ah Nahdlatul Wathan supaya tetap istiqamah berada dalam koridor syariat. 
TGH. Zainuddin tidak mewacanakan konsep tarekat Hizib, tetapi lebih pada praktiknya. Dia juga tidak mempromosikan amalan tarekat secara terbuka ke publik, hanya melibatkan jama'ah yang dianggap siap, serius dan matang menerima dan mengamalkan secara konsisten.

Selain membuat hizib, TGH. Zainuddin juga mengarang buku wasiat sebagai instrumen dakwah (Madjid 1981). Jika ulama-ulama besar membuat ratusan fatwa, TGH. Zainuddin justru menyusun buku wasiat yang juga dapat berfungsi sebagai fatwa. Wasiat ini dinamakan "Wasiat Renungan Masa" berupa sajak atau pantun. Jika dilihat dari namanya Wasiat Renungan Masa berarti pemikiran yang lahir dari refleksi pengalaman-pengalaman hidup beliau selama berkiprah di semua lini. Saya tidak akan membahas gaya bahasa dalam konteks sastra, tetapi bagaimana buku wasiat ini berperan sebagai tuntunan dalam pola hidup kaum Nahdlyiin dan sebagai otokritik. Wasiat merupakan representasi pemikiran dan refleksi TGH. Zainuddin dalam berbagai aspek baik politik, agama, ekonomi, moral, etika dan juga budaya. Wasiat tidak hanya dibaca dalam teks, tetapi juga dinyanyikan sebagai lagu yang diikuti oleh musik tradisional rabana. Setiap acara besar wasiat dibaca dalam grup kasidah dan semua jama'ah harus mendengar dengan khusuk. Internalisasi nilainilai ke-NW-an berlangsung dalam nyanyian wasiat ini. Sebagian besar jama'ah Nahdlatul Wathan menghafal bait-bait wasiat melalui nyanyian dan musik yang didengarkan di setiap kesempatan ketika ada acara-acara besar Nahdlatul Wathan. Dokumentasi nyanyian wasiat melalui CD dan kaset-kaset sangat berpengaruh dalam proses internalisasi dan indoktrinisasi nilai-nilai ke-NW-an.

Setelah TGH. Zainuddin wafat 1997, wasiat mengalami desakralisasi ketika dipolitisasi untuk kepentingan politik dan ekonomi oleh kelompok tertentu di internal Nahdlatul Wathan. Wasiat digunakan sebagai alat legitimasi kekuasan di dalam dan luar Nahdlatul Wathan dengan interpretasi yang disesuaikan untuk kepentingan masing-masing kelompok. Perubahan sosial-media pasca reformasi 1998 memberikan ruang yang lebih luas bagi para sarjana untuk mengkaji dan menafsirkan wasiat secara akademik. Tafsir wasiat juga muncul di kalangan para jama'ah sebagai acuan dan pedoman mereka megikuti arus politik dan tradisi keagamaan Nahdlatul Wathan. Peran dan fungsi wasiat semakin kuat setelah TGH. Zainuddin wafat dan diklaim sebagai salah satu karya agungnya.

\section{Ideologi Sufistik dan The Power of Public Sermon}

Untuk menjaga pola dakwah integratif dan sustainable, TGH. Zainuddin membangun tradisi unik mengadakan pengajian umum keliling ke seluruh pulau Lombok. Pengajian keliling TGH. Zainuddin bukan hanya sekedar pengajian biasa, tetapi diikuti dengan mobilesasi massa yang sangat besar. Banyak tuan guru yang lain di Lombok mengadakan pengajian keliling, tetapi mereka sangat terbatas dan tidak konsisten dan tersetruktur sebagaimana pengajian TGH. Zainuddin. Tradisi pengajian umum keliling kampung ini dilakukan oleh TGH. Zainuddin sejak aktif sebagai tokoh agama. Pengajian pada awalnya dijadikan 
sebagai media dakwah dan sosialisasi ajaran Islam dan perinsip-prinsip ke-NW-an. Tahun demi tahun pengajian ini terus dilakukan dari desa ke desa yang lain, dari satu kota ke kota lain dengan beragam respon dan tantangan sosial yang muncul di masyarakat. Tidak semua pengajian TGH. Zainuddin diterima oleh masyarakat lokal, sebagian masyarakat pernah menolak dan menghalangi pengajian beliau. Meski banyak tantangan dan cemohan, pengajian ini terus berkembang dan menjadi kekuatan kultural dan spiritual bagi TGH. Zainuddin dan jama'ahnya. Ketika sudah tidak kuat lagi berjalan karena faktor usia, TGH. Zainuddin tetap turun ke lapangan ditandu oleh para muridnya ke lokasi pengajian. TGH. Zainuddin selalu menggunakan gamis warna putih dengan sarung di dalamnya, kemudian membawa tongkat dan tasbih yang tidak pernah lepas dari tangannya.

Gerakan pengajian keliling ini menjadi salah satu identitas keagamaan Nahdlatul Wathan. Meskipun TGH. Zainuddin telah wafat tradisi pengajian keliling masih dilakukan hingga sekarang. Kedua putri beliau Ummi Rauhun dan Raihanun menggantikannya mengadakan pengajian keliling di masyarakat. Karena umur kedua putri beliau yang semakin hari semakin menua maka peran mereka digantikan oleh anak-anaknya (cucu TGH. Zainuddin) seperti TGH. Zainul Madjid, TGH. Gede Sakti Amir Murni, dan TGH. Zainuddin Astani. Pengajian keliling pada masa TGH. Zainuddin dapat dilakukan sampai tiga tempat dalam sehari yang dihadiri oleh ratusan jama'ah dari berbagai desa di sekitar pengajian. Jama'ah Nahdlatul Wathan dikenal loyal dan taat menuntut ilmu datang ke pengajianpengajian, meskipun mereka dari kecamatan atau kabupaten yang lain. Padatnya jadwal pengajian, membuat TGH. Zainuddin harus lebih selektif memilih tempat yang benarbenar mebutuhkan kehadirannya. Menurut salah satu alumni Ponpes Ma'had Darul Qur'an wal Hadist angkatan 1980an, jika jama'ah meminta pengajian ke TGH. Zainuddin maka dia akan ditanya, apa yang anda lakukan di sana (apa mek gawek lek tono), jika anda membangun madrasah atau masjid saya akan datang langsung. TGH. Zainuddin akan memprioritaskan masyarakat yang memang ada hajatnya, khususnya membangun madrasah atau masjid, bukan hanya sekedar mengundang beliau untuk pengajian biasa. Bukan rahasia umum TGH. Zainuddin selalu menekankan para alumninya setelah pulang kampung menamatkan studi, masing-masing harus membangun madrasah dan berperan aktif di masjid. Pesan ini menjadi tanggung jawab moral para alumni yang harus dilaksanakan. Selama enam dekade sejak kepulangannya dari Mekkah 1934 ratusan madrasah telah dibangun oleh para alumni di bawah bimbingan TGH. Zainuddin. TGH. Zainuddin sendiri kemudian digelari "abul madāris wa'l-masājid", bapak madrasah dan masjid karena jasa-jasa beliau membangun madrasah dan masjid (Muslim 2014).

Pengajian TGH. Zainuddin dirangkai dengan berbagai kegiatan sosial keagamaan. Acara pengajian Nahdlatul Wathan mempunyai ciri khas diantaranya adalah membaca șalawāt nahḍatain dan al-fātihah-al-fātiḥah untuk TGH. Zainuddin, guru-guru beliau dan 
kaum Muslimin di seluruh dunia. Salawāt Nahdatain adalah shalawat Nahdlatul Wathan yang disusun oleh TGH. Zainuddin yang isinya berupa kombinasi shalawat kepada Nabi Muhammad, keluarga dan para sahabatnya kemudian disambung dengan doa untuk kemakmuran dan kemajuan Nahdlatul Wathan, umat Muslim dan umat manusia secara umum. Selawat ini harus dihafal dan dibaca oleh seluruh jama'ah Nahdlatul Wathan di setiap kesempatan. Sebelum TGH. Zainuddin datang ke arena pengajian, para jama'ah sudah berkumpul mencari tempat duduk yang dekat dengan panggung pengajian tempat dia duduk. Dia didampingi oleh para tuan guru yang lain dengan kursi yang berjejer. Ketika beliau datang, panitia mengucapkan "ihtirām" dan semua jama'ah Nahdlatul Wathan berdiri dan bersama-sama menyambutnya dengan membaca doa pusaka "rabbanā ya Dhal jalāli wal minan unsuran liwa anah dathil wathan". Di akhir pengajian, para jama'ah melakukan ritual lempar uang koin ke pengajian di depan TGH. Zainuddin duduk. Ritual lempar koin ini dikenal juga dengan "shafā'atul kubrä", syafaat besar yang berarti beramal secara berjama'ah. Ratusan orang melempar koin mulai dari depan sampai belakang. Uang yang dilempar itu tidak ada putusnya, jika belum sampai ke panggung, orang yang terkena koin itu akan melemparnya kembali. Mata rantai lempar uang koin yang tidak ada putusnya ini menggambarkan adanya semangat kerja sama dan gotong royong warga Nahdlatul Wathan seperti yang dianjurkan dalam Islam 'ta'āwanū ala 'l-birri wa 't-taqwä', tolong menolong dalam kebaikan dan ketakwaan.
Ritual lempar koin untuk uang amal ini melahirkan beberapa tafsiran terkait dengan makna simboliknya. Sebagian memaknai tujuan ritual ini supaya masyarakat dapat berpartisipasi beramal dengan bebas tanpa harus mempertibangkan berapa besar uang yang dimiliki. Nilai uang koin amal tidak mempunyai makna, tetapi kebersamaan dan semangat untuk beramal itulah yang diajarkan oleh TGH. Zainuddin. Penafsiran lain juga muncul bahwa ritual lempar koin ini sama dengan melempar batu (jumrat al-'aqabah) pada ibadah haji. Jumrat al-'aqabah bertujuan untuk mengusir setan secara sumbolik dengan melempar batu kecil sebanyak tuju kali setiap tiga kali lemparan. Dalam konteks ini lempar koin sama dengan mengusir sifat-sifat setan yang tamak, rakus, dan takut untuk beramal. TGH. Zainuddin juga dapat dikatakan sebagai "bapak amal" karena di setiap saat selalu mendorong masyarakat beramal jariyah untuk donasi pembangunan gedung madrasah, pesantren dan masjid. Dalam sejarah TGH. Zainuddin tidak meminta bantuan ke pemerintah untuk membangun madrasah supaya masyarakat mempunyai ruang sosial-ibadah dalam beramal. Jika meminta bantuan ke pemerintah maka otomatis masyarakat jadi tergantung dan tidak mau beramal yang tentunya secara agama peluang untuk masuk surga semakin kecil.

Upaya TGH. Zainuddin dalam mendorong masyarakat beramal ini masih kuat diingatan masyarakat. Jika jama'ah Nahdlatul Wathan diminta untuk beramal, mereka tidak pernah berpikir dua kali jika mempunyai uang. Seandainya mereka tidak punya uang, mereka rela menjual barang mereka hanya untuk 
beramal. Kekuatan TGH. Zainuddin dalam memobilisasi massa untuk beramal masih kuat dipikiran para jama'ahnya. Bahkan ketika TGH. Zainuddin sudah wafat, para jama'ah yang berkunjung ke makam beliau tetap melestarikan budaya ritual lempar koin ke makamnya sebagai simbol kepatuhan, keihklasan dan kebersamaan dalam beramal. Berikut adalah foto makam TGH. Zainuddin yang dibanjiri dengan ritual lempar uang.

Selain ritual lempar uang koin, beberapa peristiwa unik juga terjadi di arena pengajian TGH. Zainuddin yaitu memberkati anak-anak atau para remaja dengan mengetuk kepala mereka (nyembek atau getok ulu) dengan jari telunjuk. Para jama'ah yakin jika anaknya sudah disembek maka dia telah memperoleh berkah dan akan sukses dalam kehidupannya. Masyarakat juga berebutan mengambil sisasisa dari air minum dan makanan TGH. Zainuddin yang disediakan oleh panitia pengajian. Para jama'ah yang meminta untuk diijazahkan "ilmu hikmah" juga berlangsung di arena pengajian. TGH. Zainuddin mengijazahkan mereka yang kemudian diakhiri dengan doa. Di arena pengajian juga terdapat petugas yang menjual asesoris NW berupa minyak seribu hajat, Hizib Nahdlatul Wathan, foto, kalung azimat dan cincin yang bergambar TGH. Zainuddin. Uang hasil penjualan asesoris ini disumbangkan ke madrasah dan perguruan tinggi yang sedang dibangun.

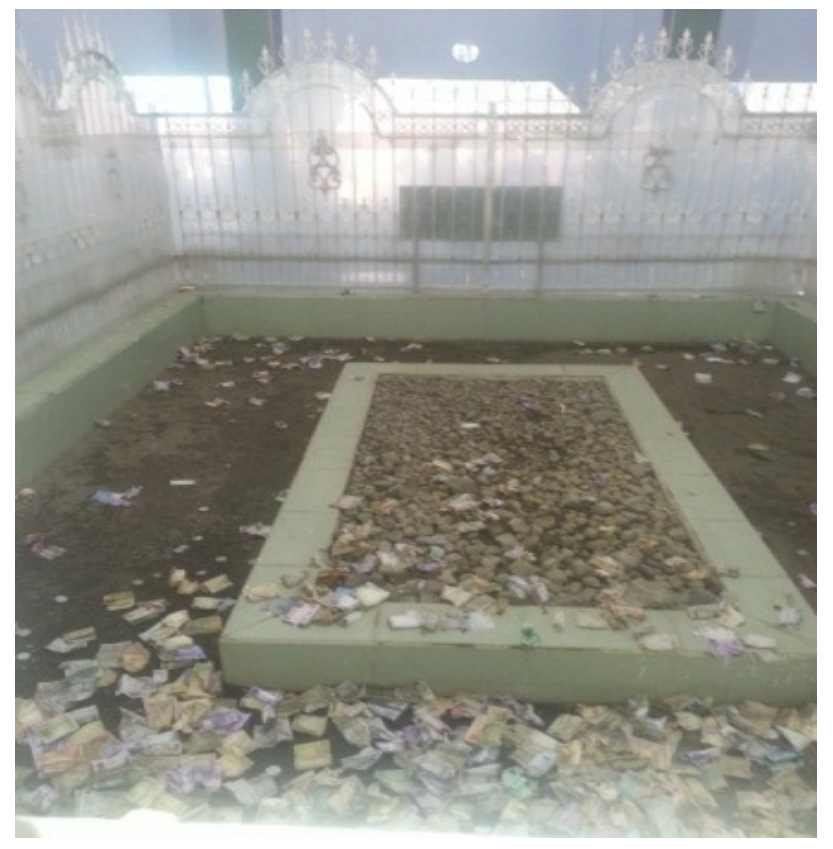

Gambar 1.

Makam TGH. Zainuddin di Pancor, Lombok Timur yang dipenuhi dengan lemparan uang amal berupa koin dan kertas dari jama'ah NW (2014) 


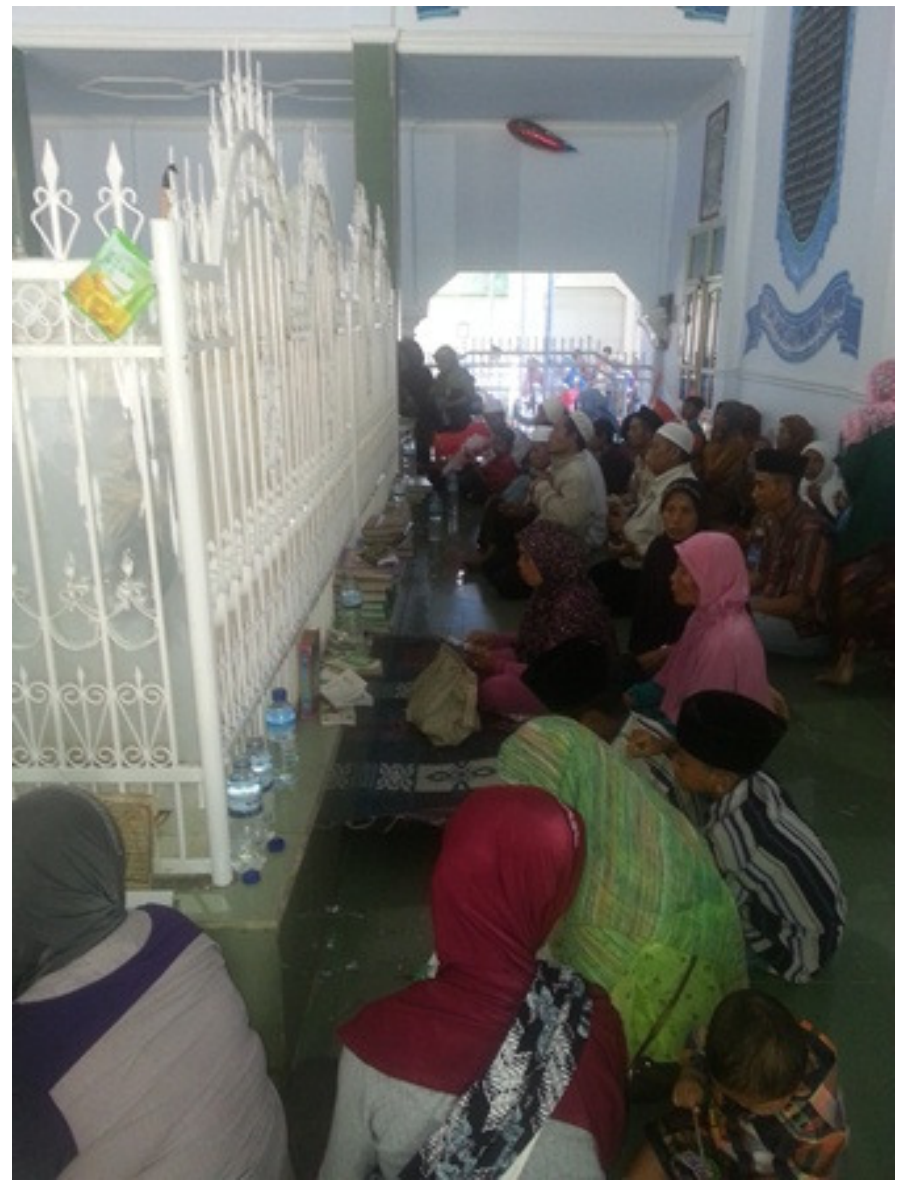

Gambar 2.

Para jama'ah NW yang sedang berdoa dan melempar uang amal di makam TGH. Zainuddin di Pancor Lombok Timur (2014)

Pengajian juga memiliki fungsi lain yakni sebagai media indoktrinisasi mulai dari pembacaan selawat, lagu-lagu mars Nahdlatul Wathan sampai dengan nyanyian Wasiat Renungan Masa. Wacana ke-NW-an yang ditanamkan pada setiap pengajian ketika ceramah oleh para tuan guru adalah bagian dari proses indoktrinisasi. TGH. Zainuddin di setiap pengajiannya selalu diawali dengan pengucapan jargon "pokoknya NW, pokok NW iman dan taqwa". Jargon Nahdlatul Wathan ini dapat diartikan, jika anda mengaku benarbenar menjadi orang Nahdlatul Wathan maka anda harus mengedepankan iman dan takwa. Nama Nahdlatul Wathan disebut terlebih dahulu sebagai jaminan jika orang-orang Nahdlatul Wathan dapat dipercaya memegang kuat iman dan taqwa. Jargon lain adalah "Inna akramakum 'indī anfa'ukum li nahḍatul wațan, wa inna sharrākum indī aḍārrukum li nahḍatul 
wațan", sesungguhnya yang paling mulia di sisiku adalah orang yang memberi manfaat bagi Nahdlatul Wathan, dan sesungguhnya yang paling buruk di sisiku adalah yang memberi mudharat bagi Nahdlatul Wathan.

Jargon atau fatwa tersebut muncul karena derasnya gelombang cobaan yang dialami oleh NW baik dari internal maupun eksternal. Banyak tokoh yang hanya memanfaatkan Nahdlatul Wathan kemudian sengaja merusak dan menggangu perjuangan Nahdlatul Wathan. Kalimat ini sempat dikritik dan digugat karena kata-katanya menyadur kalimat alQur'an yang berbunyi "Inna akramakum indallāhi atqākum". TGH. Zainuddin yang ahli sastra dan balaghah menjelaskan tentang kebolehan memodifikasi satu ayat selama memahami struktur bahasa dengan baik dan ditujukan untuk kebaikan.

Jargon yang banyak mengundang kontroversi adalah "sami'nā wa ața'nā", dengar dan taati. Jargon ini diambil dari al-Qur'an dan memunculkan kontroversi karena banyak disalahgunakan untuk kepentingan politik dan ekonomi kelompok tertentu. Sami'nā wa ața'nā yang seharusnya digunakan untuk kepentingan perjuangan dakwah dan agama mengalami manipulasi simbolik, di mana lebih difungsikan sebagai alat legitimasi kekuasaan. Jargon ini digunakan untuk memobilisasi massa urusan logistik politik. Jika terdapat jama'ah Nahdlatul Wathan yang tidak mengikuti instruksi politik pimpinan diaggap tidak akan masuk surga karena ingkar sama guru. Jangankan jama'ah Nahdlatul Wathan, para tuan guru yang sudah lama berjuang di dalamnya ikut mengalami pemecatan karena mengkritisi jargon tersebut dan berseberangan dalam ide dan gagasan. Salah seorang tuan guru dipecat karena menambahkan kata-kata wa fakkarnā sebelum kata wa ațanā. Menurut tafsir tuan guru tersebut bahwa sami'nā wa ața'nā hanya untuk kepada Allah dan Nabi, sedangkan untuk pimpinan harus sami'nā wa fakkarnā wa atạ'nā, dengar, fikirkan dan baru taati, dan itupun jika instruksi tersebut sesuai dengan syariat agama.

\section{Nasionalisme dan Soft Apparoch dalam Dakwah dan Gerakan Perjuangan}

TGH. Zainuddin dikenal sebagai tokoh yang mengedepankan cara-cara damai dalam setiap gerakan sosial keagamaannya. Dia lebih memilih 'soft approach' atau pendekatan lunak daripada pendekatan keras 'hard approach'. Ini terbukti ketika dia tidak mengikuti jejak kakaknya Tuan Guru Faesal yang mati syahid karena menyerang markas Jepang di Selong. TGH. Zainuddin tidak pernah memimpin langsung aksi konfrontasi dengan pemerintah kolonial Belanda dan Jepang. Dia meggunakan cara-cara diplomasi dan seringkali berada di balik layar. TGH. Zainuddin juga menggunakan doa-doa sebagai senjata melawan mereka yang disusun dalam bentuk buku Hizib. Dia memobilisasi massa untuk membaca Hizib dan meniatkan supaya madarasah yang dibangunnya tetap dijaga oleh Allah dan tidak dapat dibubarkan oleh rezim Jepang yang sedang menduduki daerah kepulauan Lombok.

Konsistensi sikap anti kekerasan yang ditunjukkan oleh TGH. Zainuddin juga terlihat pada masa pasca kemerdekaan. TGH. Zainuddin tidak pernah berkonfrontasi dengan 
pemerintah, bahkan sebaliknya selalu mendukung kebijakan dan membangun kerja sama dengan pemerintah pusat dan daerah. Bagi TGH. Zainuddin taat kepada pemerintah adalah bagian dari ajaran Islam. Inilah wujud politik kebangsaan TGH. Zainuddin yang dikenal religius-nasionalis. Ketika mendirikan organisasi Nahdlatul Wathan 1953, TGH. Zainuddin memilih asas Pancasila sebagai asas organisasi, bukan Islam. Menjadi pertanyaan besar kenapa beliau menggunakan Pancasila padahal tidak ada tekanan atau aturan khusus pada masa Sukarno dan awal masa Suharto untuk menggunakan Pancasila. Jelas ini semua karena sikap nasionalisme yang kuat dan visi kembangsaan yang moderat dalam diri TGH. Zainuddin. Kecerdasan dan sensitifitas sosial-politik pada diri TGH. Zainuddin serta mampu membaca masa depan merupakan kunci kesuksesan perjalanan karir politiknya di Indonesia. TGH. Zainuddin berada di tengah-tengah ketika pergulatan wacana kelompok Islam dengan nasionalis tentang asas negara. Tidak pernah terdengar sama sekali dia mewacanakan untuk mendirikan atau mendukung negara Islam, tetapi memilih Pancasila sebagai dasar negara. TGH. Zainuddin menghargai pluralitas dan local wisdom dari masyarakat. Dukungannya pada Pancasila juga terlihat pada petikan wasiat beliau dalam buku Wasiat Renungan Masa (Madjid 1981):

Negara kita ber-Pancasila,

Berketuhanan Yang Maha Esa

Ummat Islam paling setia

Tegakkan sila yang paling utama
Sikap nasionalisme dan politik anti kekerasan yang diterapkan oleh TGH. Zainuddin hampir sama dengan tokoh Mahatma Gandhi dari India. Mohandas Karamchand Gandhi adalah tokoh kemerdekaan India yang dikenal dengan anti kekerasan. Dia lahir dari keluarga pedagang yang mapan pada 02 Oktober 1886 dan wafat pada 30 Januari 1948. Dia digelari "Mahatma" yang berarti "great soul" yang berjiwa besar karena toleransi dan keterbukaannya terhadap semua etnis dan agama (Schraff 2008: 7). Setelah menyelesaikan kuliah jurusan hukum di London dia bekerja sebagai pengacara dan aktivis kemanusiaan di Afrika Selatan selama 21 tahun melawan dan menghapus apartheid. Ajaran Gandhi adalah anti kekerasan dalam menyikapi semua persoalan termasuk melawan penjajah Inggris yang sedang menduduki India. Gandhi juga dikenal sebagai tokoh anti diskriminasi, pluralisme, dan pejuang hak-ak perempuan. Ajaran Gandhi ini telah mengantarkan India sebagai negara merdeka dari Inggris tahun 1947. Gandhi akhirnya terbunuh oleh kelompok radikalis Hindu, Nathuram Godse, karena sikap politiknya yang terbuka dengan semua agama dan etnis di India termasuk kelompok Muslim.

Dalam beberapa pendekatan gerakan sosial TGH. Zainuddin dan Gandhi memiliki kemiripan, selain pendekatan yang lunak dan anti kekerasan keduanya juga dikenal moderat dalam menyikapi perbedaan. NW yang dikenal dengan kesalehan sosial jama'ahnya yang tinggi dan praktik agama yang ketat, TGH. Zainuddin sangat terbuka dengan komunitas lain seperti Hindu, China dan aliran Ahmadi- 
yah di Pancor. Beberapa kaum intelektual beragama Hindu pernah mengajar di perguruan tinggi STKIP. Ketika menerima mereka pada bulan puasa TGH. Zainuddin selalu menyediakan makanan buat mereka, walaupun dia sendiri sedang berpuasa Ramadhan. Ini dilakukan karena sangat menghormati kelompok dari agama lain. TGH. Zainuddin juga tidak pernah bersikap rasis terhadap komunitas China di Lombok, dia bahkan menerima mereka dengan tangan terbuka untuk berbisnis di Pancor. Tidak ada pemaksaan bagi mereka untuk memeluk agama Islam. Begitu juga dengan komunitas Ahmadiyah yang terdapat di Pancor (basis jama'ah Nahdlatul Wathan) diberikan kebebasan untuk berkembang bersama-sama dengan organisasi Nahdlatul Wathan. Tidak pernah terjadi kekerasan dengan komunitas Ahmadiyah selama TGH. Zainuddin masih hidup. Namun setelah beliau meninggal, Ahmadiyah mengalami kekerasan akibat perubahan sistem sosial-politik di Indonesia termasuk di Pancor. Rumah dan masjid mereka dibakar oleh massa yang berseberangan dengan paham aliran mereka.

Sebagaimana Gandhi, TGH. Zainuddin juga terjun di dunia politik praktis dan ikut memperjuangkan kemerdekaan bangsa Indonesia sejak zaman revolusi. TGH. Zainuddin sangat fleksibel dalam memilih partai politik. Dia menilai partai politik hanya sebagai media perjuangan, bukan sebagai tujuan. Pada masa Sukarno TGH. Zainuddin aktif di partai Islam Masyumi dan memegang posisi penting untuk wilayah Nusa Tengara. Partai Masyumi banyak menginspirasi TGH. Zainuddin dalam berorganisasi seperti yang terlihat dari lambang organisasi Nahdlatul Wathan yang mirip dengan lambang partai Masyumi. Setelah Masyumi dibubarkan oleh pemerintah, dia ikut mendirikan Parmusi bersama beberapa ormas Islam lainnya termasuk Muhammadiyah dan Persis. Setelah Suharto memegang kendali dan mendirikan Partai Golkar, TGH. Zainuddin kemudian ikut bergabung ke Partai Golkar. Walaupun sempat konflik dengan pengurus partai Golkar di Pemilu 1982, tetapi tidak ada konfrontasi atau kekerasan yang melibatkan jama'ahnya.

\section{Kesimpulan}

Pola pendekatan dakwah integratif TGH. Zainuddin yang melibatkan unsur budaya, seni dan politik telah menjadi kunci kesuksesannya dalam proses Islamisasi di Lombok. Pendekatan ini juga membawa TGH. Zainuddin sebagai tokoh yang tetap eksis melegenda dan mampu mengembangkan NW sebagai salah satu ormas Islam terbesar di Lombok. Kelebihan TGH. Zainuddin dibanding tokoh-tokoh Islam yang lain di Lombok adalah kemampuannya dalam mendialogkan dan mensinergikan unsur-unsur budaya lokal tersebut ke dalam praktik keagamaan yang dibangun. Praktik-praktik agama lokal Sasak bisa nyetel dengan tradisi Islam sufistik yang dikembangkan oleh TGH. Zainuddin. TGH. Zainuddin mengakomodir praktik-praktik lokal termasuk seni dan musik tradisional Sasak yang ditransformasikan ke dalam dakwahnya. TGH. Zainuddin mengubah lirik lagu Sasak dengan memasukkan nilai-nilai keislaman. Begitu juga dengan Wasiat Renungan Massa yang disusun oleh TGH. Zainuddin sangat kental nuangsa sastra Sasaknya yang 
berbentuk pantun atau lelakak, namun berisi pesan-pesan moral yang agung.

Kultur Islam sufistik yang dibangun oleh TGH. Zainuddin di Lombok tidak lepas dari nilai-nilai lokalitas budaya Sasak. Ritual lempar koin secara bersama-sama untuk uang amal adalah simbol kebersamaan dan kekeluargaan masyarakat Sasak yang tidak mengenal status sosial. Begitu juga semangat gotong royong dalam membangun madrasah mulai dari angkut pasir dan batu dari parit, dan menebang pohon untuk kelengkapan pembangunan gedung madrasah yang dimobilisir oleh TGH. Zainuddin. Berhizib secara berjama'ah juga bagian dari tradisi masyarakat Lombok yang mengedepankan ikatan komunalitas. Pengajian umum (public sermon) yang didesain TGH. Zainuddin menjadi ruang sosial bagi masyarakat Sasak dan jama'ah Nahdlatul Wathan untuk memperkuat solidaritas dan integrasi komunalitas dan familialitas mereka.

Sikap anti kekerasan dan anti diskriminasi yang ditunjjukkan TGH. Zainuddin selama memimpin Nahdlatul Wathan dan menjadi tokoh agama adalah pelajaran yang penting bagi masyarakat Lombok pada umumnya dan generasi Nahdlatul Wathan pada khususnya. Setiap masalah dapat dislesaikan dengan jalan damai, bukan dengan konflik dan kekerasan. Ideologi inklusivisme dan pluralisme TGH. Zainuddin dalam membangun relasi sosial tanpa memandang etnis dan agama seseorang merupakan nilai universal dan modal sosial dalam kultur sosial keagamaan Nahdlatul Wathan. Jika melihat konsep dan ideologi bermasyarakat dan bernegara yang dicontoh- kan oleh TGH. Zainuddin maka untuk menjadi jama'ah Nahdlatul Wathan yang taat, tidak harus menutup diri dari komunitas lain dan sebaliknya harus memperbanyak kerja sama yang bisa mendatangkan manfaat bagi agama dan organisasi Nahdlatul Wathan.[]

\section{Daftar Pustaka}

Baharuddin. 2007. Nahdlatul Wathan dan Perubahan Sosial. Yogyakarta: Genta Press.

Binbaș, İlker Evrim. 2005. "Music and Samā' of the Mavlaviyya in the Fifteenth and Sixteenth Centuries: Origins, Ritual, and Formation." dalam Sufism, Music And Society In Turkey And The Middle East, ed. A. Hammarlund, T. Olsson, dan E. Özdalga. Istanbul: Swedish Research Institute in Istanbul Transactions.

Budiwanti, Erni. 2000. Islam Sasak: Wetu Telu versus Waktu Lima. Yogyakarta: LKiS.

Durkheim, Emile. 1995. The Elementary Forms of Religious Life. New York: The Free Press.

Habib, M. dan M. Zuhdi. 2012. Hizib dan Thariqat Hizib Nahdlatul Wathan: Alternatif Tasawuf Modern. Jakarta: Pesantren NW Jakarta.

Hadi, Abdul. 2010. "Charismatic Leadership and Traditional Islam in Lombok: History and Conflict in Nahdlatul Wathan." Masters Thesis. Australian National University, Canberra.

Hamdi, Saipul. 2014. Nahdlatul Wathan di Era Reformasi: Agama, Konflik Komunal dan Peta Rekonsiliasi. Yogyakarta: KKS.

Hamdi, Saipul. 2011. "Politik Islah: Renegosiasi Islah, Konflik dan Kekuasaan dalam 
Nahdlatul Wathan di Lombok Timur." Jurnal Kawistara 1(1):1-14.

Hamdi, Saipul dan Bianca J. Smith. 2012. "Sisters, Militias and Islam in Conflict: Questioning 'Reconciliation' in Nahdlatul Wathan, Lombok, Indonesia.” Contemporary Islam 6(1):29-43. Retrieved (http://link.springer.com/10.1007/s11 562-011-0168-5).

Jamaludin. 2011. Sejarah Sosial Islam di Lombok Tahun 1740-1935 (Studi Kasus terhadap Tuan Guru). Jakarta: Puslitbang Lektur dan Khazanah Keagamaan Badan Litbang dan Diklat Kementrian RI.

Jasper, David. 2006. The Sacred Desert Religion, Literature, Art, and Culture. Malden: Blackwell Publishing.

Madjid, Zainnuddin Abd. 1981. Wasiat Renungan Masa. Selong: Hamzanwadi.

Nahdi, Khirjan. 2012. Nahdlatul Wathan dan Peran Modal: Studi Etnografis-Historis Modal Spiritual dan Modal Sosial Kultural. Yogyakarta: Insyira.

Noor, Mohammad, ed. 2004. Visi Kebangsaan Religius: Refleksi Pemikiran dan Perjuangan Tuan guru Kyai Haji Muham- mad Zainuddin Abdul Madjid 1904-1997. Jakarta: Logos Wacana Ilmu.

Nu'man, Hayyi. 1999. TGH. Zainuddin TGKH. Muhammad Zainuddin Abdul Madjid: Riwayat Hidup dan Perjuangannya. Mataram: Pengurus Besar Nahdlatul Wathan.

Schraff, Anne. 2008. Mahatma Gandhi. Irvine, CA.: Saddleback Educational Publishing.

Smith, Bianca J. 2012. "Re-orienting Female Spiritual Power in Islam." Indonesia and the Malay World 40(118): 249-71. Retrieved (http://www.tandfonline.com /doi/abs/10.1080/13639811.2012.710 423).

Smith, Bianca J. 2014. "Stealing Women, Stealing Men: Co-creating Cultures of Polygamy in a Pesantren Community in Eastern Indonesia." Journal of International Women's Studies 15(1): 118-35.

Syakur, Ahmad Abd. 2006. Islam dan Kebudayaan: Akulturasi Nilai-nilai Islam dalam Budaya Sasak, TGHKH. M. Zainuddin Abdul Madjid Agen Pembaharuan Budaya Sasak 1904-1997. Yogyakarta: Adab Press. 
This page is intentionally left blank 